\title{
Comparison of yield damage of tropical maize hybrids caused by anthracnose stalk rot
}

\author{
Rodrigo R. Matiello', Maria Teresa G. Lopes², Kátia R. Brunelli³ \& Luis Eduardo A. Camargo ${ }^{4}$ \\ ${ }^{1}$ Departamento de Fitotecnia e Fitossanidade, Universidade Estadual de Ponta Grossa, 84030-900, Ponta Grossa, PR, Brasil; \\ ${ }^{2}$ Departamento de Produção Animal e Vegetal, Universidade Federal do Amazonas, Faculdade de Ciências Agrárias, 69077- \\ 000, Manaus, AM, Brasil; ${ }^{3}$ Sakata Seed Sudamerica, Estrada da Bocaina s/n, 12906-840, Bragança Paulista, SP, Brasil; \\ ${ }^{4}$ Departamento de Fitopatologia e Nematologia, Universidade de São Paulo - Escola Superior de Agricultura "Luiz de \\ Queiroz", Cx. Postal 09, 13418-900, Piracicaba, SP, Brasil
}

Author for correspondence: Rodrigo R. Matiello, e-mail: rrmatiel@uepg.br

\begin{abstract}
The objective of this study was to estimate the reduction in yield caused by Colletotrichum graminicola in resistant and susceptible maize hybrids inoculated at different stages of development. Two trials were conducted in different environmental conditions in a randomized block design with treatments arranged as a $2 \times 5$ factorial scheme and three replications. Treatments consisted of two hybrids (H8664, resistant and H8621, susceptible) inoculated at three growing stages (8-leaf, 12-leaf and tasseling stage). Internal lesion length, adjusted yield, and yield components (length, diameter and ear weight) were evaluated 120 days after emergence. Significant differences in yield and ear weight were detected in the susceptible hybrid inoculated at the earliest stage: yield was reduced by 16.1 and $20.2 \%$ in the first and second experiment, respectively. Although lesion length in the susceptible hybrid was approximately three times greater than in the resistant, there were no significant differences in lesion length among treatments for each hybrid. However, there were differences in the number of dead plants and ear weight. It is suggested that damage caused by early infection with C. graminicola results mainly from plant death and reduction in ear weigh rather than from the extent of colonization of the stalk.
\end{abstract}

Key words: Colletotrichum graminicola, Zea mays, disease.

\section{INTRODUCTION}

Diverse fungal pathogens cause stalk rot in maize, including Gibberella zeae (Schwein.) Petch, Colletotrichum graminicola (Ces.) G. W. Wils, Stenocarpella maydis (Berk.) Sutton and Bipolaris zeicola (G.L. Stout) Shoemaker. In Brazil, C. graminicola is one of the most predominant causal agent of the anthracnose stalk rot (ASR) and represents an increasing threat to maize crops (Denti \& Reis, 2003; Costa et al., 2010). The incidence of the disease in Brazil increased after the widespread adoption of a second cropping in autumn-winter (the so-called "safrinha" crop), when higher temperatures and humidity at the beginning of planting favor the disease, and both the use of no-tillage cultivation and no crop rotation (Byrnes \& Carrol, 1986), since the pathogen survives in crop residues (Naylor \& Leonard, 1977; Lipps, 1988; Bergstrom \& Nicholson, 1999). C. graminicola infects roots, stalks, leaves, ears and kernels (Venard \& Vaillancourt, 2007; Muimba-Kankolongo \& Bergstrom, 2011). Infection of the stalks may arise from direct penetration of conidia produced on blighted leaves (White et al., 1979) or from penetration through injuries caused by insects in the stalks (Bergstrom et al., 1983; Keller et al., 1986). In some countries such as France, India, and the Philippines, this disease is a limiting factor for maize production (Shurtleff, 1999). In the United States, severe stalk rot epidemics occurred in the 1980's, which resulted in reductions in yield quantity (damages) of up to $28 \%$ (Carson \& Hooker, 1982). Herein, the term damage is used according to Zadoks (1985) meaning any reduction in yield quantity and/ or quality.

Damages from stalk rot result from the internal destruction of tissues that can cause plant lodging or death. In this case, grain quality is compromised due to decay of the ears that are in contact with the soil (Christensen \& Wilcoxson, 1966; Jarvis et al., 1984; Muimba-Konkolongo \& Bergstrom, 1992; Shurtleff, 1999). In addition, infected plants present reduced grain yield due to low kernel weight (Dodd, 1980). Most investigations of yield damages caused by $C$. graminicola in maize were conducted under conditions of natural infection and this may explain their somewhat discrepant results. Perkins \& Hooker (1979), for instance, observed both an increase of $11 \%$ and a decrease of $17 \%$ in grain yield depending on the plant genotype, whereas other studies did not find significant associations between reductions in grain yield and infection (Callaway et al., 1992; Denti \& Reis, 2001; Denti \& Reis, 2003). However, Keller et al. (1986) reported reductions in yield of up to $35 \%$ when plants were infected in the whorl stage, but no reduction when plants were infected in the dough stage, suggesting 
that the magnitude of damages depends on the phenological stage of the host when infection occurs. In Brazil, there are no estimates of damages caused by anthracnose stalk rot evaluated under controlled experimental conditions; however, field observations indicated that damages of up to $40 \%$ can occur (Nazareno, 1989).

Precise estimates of yield damage due to ASR are difficult to obtain since the symptoms are internal and development of the disease is highly dependent on environmental and host conditions (Keller et al., 1986). Thus, the objective of this study was to estimate damages on grain yields in two tropical maize hybrids artificially inoculated with $C$. graminicola at three growth stages in the two main annual growing seasons of maize.

\section{MATERIALS AND METHODS}

Plant material consisted of the resistant hybrid H8664 and the susceptible H8621. The former was obtained by crossing inbred lines derived from Amarillo Dent and Caribbean Flint types whereas the latter was obtained by crossing inbred lines derived from this population with lines from Suwan DMR, which is a population developed in Thailand through selection of tropical genotypes containing Caribbean and Tuxpeño types (Coêlho et al., 2001; Lanza et al., 1999).

The isolate of C. graminicola "Iraí de Minas" was grown on oatmeal agar medium (40 g oatmeal, $17 \mathrm{~g}$ agar, and $1 \mathrm{~L}$ distilled water) in a growth chamber under controlled temperature $\left(22 \pm 2^{\circ} \mathrm{C}\right)$ and a $12 \mathrm{~h}$ dark $/ 12 \mathrm{~h}$ fluorescent light photoperiod for approximately 14 days. Inoculum was prepared by adding $20 \mathrm{~mL}$ of distilled water to the petri dishes and scraping the surface of the culture with a scalpel to release the conidia. The spore suspension was filtered through a double layer of cheesecloth, and its concentration was adjusted to $1.8 \times 10^{5}$ conidia $\mathrm{mL}^{-1}$. One droplet of Tween $80 \%$ was added as a wetting agent per liter of inoculum.

Hybrids were inoculated at the 8-leaf, 12-leaf and tasseling stages, which correspond to the 2, 3 and 4 developmental stages, respectively (Fancelli, 1986). Plants were injected with $1 \mathrm{~mL}$ of the spore suspension in the first internode above the soil surface using a veterinary syringe (White \& Humy, 1976). Plots with plants inoculated with $1 \mathrm{~mL}$ of sterile water during phenological stage 2 and noinoculated were used as control treatments.

Two trials were set up according to a randomized blocks design with treatments arranged as a 2 (hybrids) $\times$ 5 (3 inoculation stages and 2 controls) factorial with three replications. The experimental unit consisted of a two-row plot $5 \mathrm{~m}$ long, spaced by $0.9 \mathrm{~m}$ and containing approximately 25 plants per row, which corresponds to a planting density of 55000 plants ha ${ }^{-1}$. The trials were conducted in Piracicaba (São Paulo, Brazil) in October (regular planting season) and December (late planting season) of 2002.

Grain yield was measured at the maturity period (stage 10) by weighting the kernels. Yield data per plot were adjusted to tons per hectare at $13 \%$ moisture. Internal ASR lesion length $(\mathrm{cm})$ was measured from 5 plants per plot chosen at random after longitudinally cutting the plants with an electric saw. The length, diameter, and weight of ears were also determined for 5 plants $^{\text {plot }}{ }^{-1}$ for estimation of yield components. The number of plants per plot was recorded before inoculation and at the end of the experiment.

Data of each trial were used for analysis of variance using the PROCANOVA procedure of the SAS software (SAS Institute, 2000) and treatment means were compared by Tukey's test $(p=0.05)$.

\section{RESULTS AND DISCUSSION}

The joint ANOVA of the two trials indicated significant $(p<0.05)$ hybrid $\mathrm{x}$ trial interactions. Thus, ANOVAs were performed individually for each trial. Statistical differences $(p<0.05)$ in lesion length were detected between hybrids indicating that they differ in their degree of resistance to the pathogen, as expected. The resistance of H8664 is noteworthy, since the mean lesion length averaged over inoculation stages was approximately 3 times shorter than in the susceptible hybrid (Table 1). This level of resistance was also found in tropical hybrids and inbred lines inoculated with C. graminicola in the first internode above of the soil surface (Pereira et al., 1989; Muimba-Kankolongo \& Bergstrom, 2011) and in hybrids with the major resistance gene Rcgl (Frey et al., 2011).

In general, the hybrids also differed for yield and yield components in both trials due to differences in their genetic constitution. Significant interactions were detected between hybrids and inoculation stages for lesion length, yield and number of plants by plot in both trials, and also for ear weight in the second trial. However, the partitioning of these interactions indicated that the significance of the interaction between hybrid and lesion length was due to differences between pathogen-inoculated treatments and the water control treatment for both hybrids (Table 1). On the other hand, differences in yield and in the number of plants per plot in both trials and in ear weight in the second trial were significant $(p<0.01)$ only in the susceptible hybrid H8621. In this case, mean comparisons indicated that yield was reduced only when plants were inoculated with the pathogen at the 8-leaf stage (Table 2 ), indicating that early infection affected yield. Yields were $16.1 \%$ and $20.2 \%$ lower than in the non-inoculated controls, in the first and second trials, respectively. These results agree with an earlier report by Warren \& Nicholson (1975), which also reported yield reductions related to infections during the early reproductive stages, and are similar in magnitude to those reported by Keller et al. (1986), who found average damage of $21.6 \%$ in plants of the susceptible temperate inbred line Cornell 281 infected at the whorl stage. However, in contrast to what was observed in this study, these authors also reported damages of $16 \%$ 
TABLE 1 - Mean lesion length in two trials of maize hybrids inoculated with C. graminicola at the 8-leaf, 12-leaf and tasseling growth stages and inoculated with water at the 8-leaf stage (control-water)

\begin{tabular}{lcccc}
\hline \hline & \multicolumn{3}{c}{ Trial 1 } & \multicolumn{2}{c}{ Trial 2 } \\
\cline { 2 - 5 } Inoculation stage & $\mathbf{H 8 6 2 1}(\mathbf{S})$ & $\mathbf{H 8 6 6 4 ( \mathbf { R } )}$ & $\mathbf{H 8 6 2 1}(\mathbf{S})$ & H8664 (R) \\
\hline 8-leaf & $67.1 \mathrm{a}^{1}$ & $23.9 \mathrm{a}$ & $58.9 \mathrm{a}$ & $17.2 \mathrm{a}$ \\
12-leaf & $68.3 \mathrm{a}$ & $19.7 \mathrm{a}$ & $56.5 \mathrm{a}$ & $16.9 \mathrm{a}$ \\
tasseling & $65.8 \mathrm{a}$ & $22.9 \mathrm{a}$ & $59.7 \mathrm{a}$ & $4.3 \mathrm{a}$ \\
Control-water & $6.5 \mathrm{~b}$ & $5.4 \mathrm{~b}$ & $4.6 \mathrm{~b}$ & $3.6 \mathrm{~b}$ \\
\hline
\end{tabular}

${ }^{1}$ Means within columns followed by different letters are significantly different $(p<0.05)$ based on Tukey's test. R and S, resistant and susceptible hybrids.

TABLE 2 - Mean grain yield and ear weight of two hybrids inoculated with C. graminicola at the 8-leaf, 12-leaf and tasseling stages and non-inoculated (control) or inoculated with water at the 8-leaf stage (control-water)

\begin{tabular}{|c|c|c|c|c|c|c|}
\hline \multirow{3}{*}{ Inoculation stage } & \multicolumn{4}{|c|}{ Yield $\left(\mathrm{t} \mathrm{ha}^{-1}\right)$} & \multicolumn{2}{|c|}{ Ear Weight (g) } \\
\hline & \multicolumn{2}{|c|}{ Trial 1} & \multicolumn{2}{|c|}{ Trial 2} & \multicolumn{2}{|c|}{ Trial 2} \\
\hline & H8621 (S) & H8664 (R) & H8621 (S) & H8664 (R) & H8621 (S) & H8664 (R) \\
\hline 8-leaf & $9.4 \mathrm{~b}^{1}$ & $7.7 \mathrm{a}$ & $8.3 \mathrm{~b}$ & $8.3 \mathrm{a}$ & $228 \mathrm{~b}$ & $199 \mathrm{a}$ \\
\hline 12-leaf & $11.7 \mathrm{a}$ & $7.9 \mathrm{a}$ & $10.9 \mathrm{a}$ & $8.1 \mathrm{a}$ & $258 \mathrm{a}$ & $204 \mathrm{a}$ \\
\hline tasseling & $10.2 \mathrm{a}$ & $7.8 \mathrm{a}$ & $10.4 \mathrm{a}$ & $8.6 \mathrm{a}$ & $254 \mathrm{a}$ & $217 \mathrm{a}$ \\
\hline control & $11.2 \mathrm{a}$ & $7.8 \mathrm{a}$ & $10.4 \mathrm{a}$ & $8.7 \mathrm{a}$ & $268 \mathrm{a}$ & $200 \mathrm{a}$ \\
\hline control-water & $11.2 \mathrm{a}$ & $7.9 \mathrm{a}$ & $10.1 \mathrm{a}$ & $8.0 \mathrm{a}$ & $253 \mathrm{a}$ & $204 \mathrm{a}$ \\
\hline
\end{tabular}

${ }^{1}$ Means within columns followed by different letters are significantly different $(p<0.05)$ based on Tukey's test. R and S, resistant and susceptible hybrids.

in plants infected at the tasseling stage. This discrepancy could be due to differences in resistance between hybrids and experimental conditions. Recently, Frey et al. (2011) reported that the presence of a major resistance gene to ASR reduced the overall impact of the disease in yield by almost three fold in comparison to susceptible hybrids.

Pereira (1983) comparing the severity of anthracnose on seedlings and adult plants of maize in various genotypes, observed that in some of them there were correspondence and in others not. Evaluated the area affected by the lesions of the stalk, and not only the lesion length, achieving more precise in the evaluation of the disease and discrimination of resistance among genotypes. In this work, we evaluated the internal length of the lesion because it is difficult to accurately estimate the lesioned area in the stalks.

An important aspect of our results is that in the inoculated treatments there was no difference in lesion length within hybrids regardless of the inoculation stage (Table 1), suggesting that reductions in yield associated to infection at the beginning of the growth stage in the susceptible hybrid were not due to differences in lesion development among inoculation stages. Thus, it seems likely that infections at the beginning of the crop interfere in the process of sugar accumulation in the stalk, which occur mainly during this time and will influence grain filling later, rather than from the magnitude of the damage of plant tissues caused by the pathogen. This hypothesis is supported by the observation that ear weight was reduced only in plants inoculated at the 8-leaf stage $(20.3 \%)$ in the second trial (Table 2). Borges et al. (2001) observed the same behavior as the lesion length of stalk rot caused by Fusarium moniliforme.

Additionally, another factor that contributed to lower yields was the increased number of dead plants. The frequency of dead plants displaying typical symptoms of stalk rot was higher in plots of the susceptible hybrid inoculated at the 8-leaf stage than in any other treatment (Table 3). At the end of the cycle, these plots had an average of 31 plants compared to 40 plants in the control treatment inoculated with water. In contrast, the number of plants in all plots of the resistant hybrid (H8664) ranged from 36 to 39 (Table 3). Likewise, in anthracnose stalk caused by Fusarium, Afolabi et al. (2008) reported that severe stalk rot in the early stage also affected yield through premature plant death or lodging in maize.

Our results demonstrate that yield damages due to anthracnose stalk rot in tropical conditions are within the same range of those reported for temperate maize crops. Also, the magnitude of damages varies according to the growth stage at the time of infection. We suggested that damages caused by early infection (8-leaf stage) for $C$. graminicola result from death of the plants, reductions in ear weight and, possibly, an interference of the pathogen in the metabolism of the stalk for a longer period of time. Additionally, the high level of resistance of the hybrid H8664 indicates the potential to explore tropical maize germplasm as a source of genetic resistance to C. graminicola in breeding programs in Brazil. 
Comparison of yield damage of tropical maize hybrids caused by anthracnose stalk rot

TABLE 3 - Number of plants by plot at maturity in two trials of hybrids inoculated with C. graminicola at the 8-leaf, 12-leaf and tasseling stages and non-inoculated (control) or inoculated with water at the 8-leaf stage (control-water)

\begin{tabular}{lcccc}
\hline \hline & & Trial 1 & & Trial 2 \\
\hline Inoculation stage & H8621 (S) & H8664 (R) & H8621 (S) & H8664 (R) \\
\hline 8-leaf & $30 \mathrm{~b}^{1}$ & $37 \mathrm{a}$ & $33 \mathrm{~b}$ & $37 \mathrm{a}$ \\
12-leaf & $41 \mathrm{a}$ & $37 \mathrm{a}$ & $41 \mathrm{a}$ & $38 \mathrm{a}$ \\
tasseling & $42 \mathrm{a}$ & $39 \mathrm{a}$ & $41 \mathrm{a}$ & $36 \mathrm{a}$ \\
control & $41 \mathrm{a}$ & $37 \mathrm{a}$ & $40 \mathrm{a}$ & $36 \mathrm{a}$ \\
control-water & $39 \mathrm{a}$ & $37 \mathrm{a}$ & $40 \mathrm{a}$ & $38 \mathrm{a}$ \\
\hline
\end{tabular}

${ }^{1}$ Means within columns followed by different letters are significantly different based on $(p<0.05)$ Tukey's test. R and S, resistant and susceptible hybrids.

\section{ACKNOWLEDGMENTS}

We thank Dow AgroSciences LLC - Seed Company for the technical support. This study was supported by Coordenação de Aperfeiçoamento de Pessoal de Nível Superior - CAPES - PICDT/UEPG and Fundação de Apoio à Pesquisa do Estado de São Paulo - FAPESP through grant 01/02793-0. LEAC is supported by a fellowship from Conselho Nacional de Desenvolvimento Científico e Tecnológico - CNPq.

\section{REFERENCES}

Afolabi CG, Ojiambo PS, Ekpo EJA, Menkir A, Bandyopadhyay R (2008) Novel sources of resistance to Fusarium stalk rot of maize in tropical Africa. Plant Disease 92:772-780.

Bergstrom GC, Croskey BS, Carruthers RI (1983) Synergism between Colletotrichum graminicola and European corn borer in stalk rot of corn in New York. Phytopathology 73:842 (Abstract).

Bergstrom GC, Nicholson RL (1999) The biology of corn anthracnose: knowledge to exploit for improved management. Plant Disease 83:596-608.

Borges MF, Resende ML, Von Pinho RG (2001) Inoculação artificial de colmos de milho em diferentes idades e concentrações de inóculo e sua relação com a expressão da resistência a Fusarium moniliforme. Fitopatologia Brasileira 26:715-720.

Byrnes KL, Carrol RB (1986) Fungi causing stalk rot of conventionaltillage and no-tillage corn in Delaware. Plant Disease 70:238 (Abstract).

Callaway MB, Smith ME, Coffman WR (1992) Effect of anthracnose stalk rot on grain yield and related traits of maize adapted to the northeastern United States. Canadian Journal of Plant Sciences 72:1031-1036.

Carson ML, Hooker AL (1982) Reciprocal translocation testcross analysis of genes for anthracnose stalk rot resistance in a corn inbred line. Phytopathology 72:175-177.

Christensen JJ, Wilcoxson RD (1966) Stalk rot of corn. Monogr. 3. St. Paul MN, USA. American Phytopathological Society.

Coêlho RMS, Silva HP, Brunelli KR, Camargo LEA (2001) Controle genético da antracnose foliar. Fitopatologia Brasileira 26:640-643.

Costa RV, Silva DD, Cota LV, Parreira DF, Ferreira ASF, Casela CR (2010) Incidência de Colletotrichum graminicola em colmos de genótipos de milho. Summa Phytopathologica 36:122-128.

Denti EA, Reis EM (2001) Efeito da rotação de culturas, da monocultura e da densidade de plantas na incidência das podridões da base do colmo e no rendimento de grãos de milho. Fitopatologia Brasileira 26:635-639.

Denti EA, Reis EM (2003) Levantamento de fungos associados às podridões do colmo e quantificação de danos em lavouras de milho do planalto médio gaúcho e dos Campos Gerais do Paraná. Fitopatologia Brasileira 28:585-590.

Dodd J (1980) The role of plant stresses in development of corn stalk rots. Plant Disease 64:533-537.

Fancelli AL (1986). Plantas alimentícias: guia para aula, estudo e discussão. Piracicaba SP. USP, ESALQ/CALQ.

Frey TJ, Weldekidan T, Colbert T, Wolters PJCC, Hawk JA (2011) Fitness evaluation of Rcg1, a locus that confers resistance to Colletotrichum graminicola (Ces.) G. W. Wils. using near-isogenic maize hybrids. Crop Science 51:1551-1563.

Jarvis JL, Clark RL, Guthrie WD, Berry EC, Russel WA (1984) The relationship between second generation European corn borers and stalk rot fungi in maize hybrids. Maydica 24:247-263.

Keller NP, Bergstrom GC, Carruthers RI (1986) Potential yield reductions in maize associated with an anthracnose/European corn borer pest complex in New York. Phytopathology 76:586-589.

Lanza LLB, Souza Jr, CL, Ottoboni LMM, Vieira MLC, Souza AP (1999) Genetic distance of inbred lines and prediction of maize single-cross performance using RAPD markers. Theoretical and Applied Genetics 94:1023-1030.

Lipps PE (1988) Spread of corn anthracnose from surface residues in continuous corn and corn-soybean rotation plots. Ecology and Epidemiology 78:756-761.

Muimba-Kankolongo A, Bergstrom GC (1992) Wound predisposition of maize to anthracnose stalk rot as affected by internode position and inoculum concentration of Colletotrichum graminicola. Plant Disease 76:188-195.

Muimba-Kankolongo A, Bergstrom GC (2011) Reduced anthracnose stalk rot in resistant maize is associated with restricted development of Colletotrichum graminicola in pith tissues. Journal of Phytopathology 159:329-341

Naylor DV, Leonard KJ (1977) Survival of Colletotrichum graminicola in infected corn stalks in North Carolina. Plant Disease Reporter 61:382-383.

Nazareno NRX (1989) Avaliação de perdas por podridão do colmo em milho (Zea mays) no Estado do Paraná. Fitopatologia Brasileira 
$14: 82-84$

Pereira OAPP (1983) Herança da resistência à podridão de colmo em milho (Zea mays L.) causada por Colletotrichum graminicola (Ces.) Wils. DS Thesis, ESALQ/USP. Piracicaba SP.

Pereira OAPP, Balmer E, Miranda Filho JB (1989) Inheritance of resistance to stalk rot, caused by Colletotrichum graminicola (Ces.) Wils, in maize (Zea mays L.). Revista Brasileira de Genética 12:5365.

Perkins JM, Hooker AL (1979) Effects of anthracnose stalk rot on corn yields in Illinois. Plant Disease Reporter 63:26-31.

SAS Institute Inc (2000). SAS/STAT user guide, Version 8.1. Cary NC, USA.

Shurtleff MC (Ed.) (1999) Compendium of Corn Diseases. St Paul MN, USA. APS Press.
Venard C, Vaillancourt L (2007) Colonization of fiber cells by Colletotrichum graminicola in wounded maize stalks. Phytopathology 97:438-447.

Zadoks JC (1985) On the conceptual basis of crop loss assessment: the threshold theory. Annual Review of Phytopathology 23:455473.

Warren HL, Nicholson RL (1975) Kernel infection, seedling blight, and wilt of maize caused by Colletotrichum graminicola. Phytopathology 65:620-623.

White DG, Humy C (1976) Methods for inoculation of corn stalks with Colletotrichum graminicola. Plant Disease Reporter 60:898899.

White DG, Yanney J, Natti TA (1979) Anthracnose stalk rot. In: Proceedings of the 34th Annual Corn and Sorghum Research Conference. Chicago IL, USA. p.1-15.

TPP 538 - Received 9 March 2012 - Accepted 8 November 2012 Section Editor: Lilian Amorim 